\author{
Illés Kristóf
}

\title{
PARKOLÓPÁLYA VAGY AUTÓPÁLYA AZ M3 BUSINESS CENTER? ${ }^{1}$
}

\section{SZABÁLYSÉRTÉS A GYAKORLATBAN, KÜLÖNÖS TEKINTETTEL A FÖVÁROS HELYZETÉRE}

\author{
Jurisprudence of Administrative Offences with Special Regard to the Situtation in the \\ Capital
}

Dr. Illés Kristóf bírósági fogalmazó, Fővárosi Törvényszék, illeskristof46@gmail.com

A tanulmány célja annak bemutatása, hogy Magyarország bíróságai miként vesznek részt a szabálysértésekkel összefüggő jogalkalmazásban, illetőleg betekintést adni a fóvárosban zajló peres és nemperes szabálysértési itélkezés volumenébe és minőségébe a statisztikai adatok elemzése útján, kiegészitve mindezt a bíróság jogalkalmazói tevékenysége körében felmerülő nehézségek bemutatásával, amihez a szerző közvetlen jogalkalmazói tapasztalata szolgál alapul. A kutatás eredményeként megállapitható volt, hogy az utóbbi években a Pesti Központi Kerületi Bíróság Szabálysértési Csoportjának ügyérkezése folyamatosan csökkent, de az egy före jutó ügyteher magas. A vizsgált csoportban eljáró, döntöen bírósági titkárokat többrétü kihívások érik. Elsösorban az eljárási határidők rövidsége, valamint hogy a rendörség által szabálysértési ügyekkel összefüggésben folytatott elökészitö eljárások alapossága gyakran elmarad a büntetöügyek vonatkozásában végzett munkától. Mindezek ellenére a munkavégzés színvonala magas, ezt támasztja alá, hogy az elmúlt években a folyamatban maradt ügyek száma évröl évre csökkent, a szabálysértési elzárással is büntethetö ügyekben meghozott ügydöntő végzéseknek csak csekély számát támadta fellebbezés, és a fellebbezett ügyek tekintetében is kimagasló arányban született helybenhagyó másodfokú döntés.

A szójáték alapja, hogy az előadás idején a Pesti Központi Kerületi Bíróság Szabálysértési Csoportja a 1146 Budapest, Hungária körút 179-187. szám alatt az M3 Business Center épületének VIII. emeletén müködik. 


\section{KulcssZAvAK:}

bírósági titkár, helyszíni bírság, szabálysértés, szabálysértési eljárás, szabálysértési elzárás, pénzbírság, ügyteher, ügyérkezés

The aim of this paper is to present how the courts of Hungary participate in the application of law related to administrative offences, and to give an insight into the volume and quality of settlements of litigation and non-litigation cases in the capital by analysing statistical data and also to present the upcoming difficulties during the process which is based on the author's direct legal experience. As a result of the research, it could be stated that in the last years the number of the new cases of the Administrative Offence Group of the Central District Court of Pest has been steadily declining, but the per capita case burden is high. The group in question, where mainly senior court officials work, face a number of challenges. In particular, the shortness of procedural deadlines and the thoroughness of the police's preparatory procedures for cases related to administrative offences, often lag behind the work done in criminal matters. Nevertheless, the standard of work is high, as evidenced by the fact that the number of pending cases has decreased year by year in recent years, only a small number of orders have been appealed and a high proportion of appealed decisions have been confirmed by the upper tribunal.

\section{KEYWORDS:}

administrative offence, case burden, on the spot penalty, pecuniary penalty, senior court official 


\section{BEVEZETÉS}

Jelen tanulmány a fenti cím alatt, a Nemzeti Közszolgálati Egyetemen 2019. november 29. napján elhangzott előadás gondolatait rögzíti írásos formában. Célja annak bemutatása, hogy Magyarország rendes bíróságai miként vesznek részt a szabálysértésekkel összefüggö jogalkalmazásban, illetőleg betekintést adni a fővárosban zajló peres és nemperes szabálysértési ítélkezés volumenébe és minőségébe a statisztikai adatok elemzése útján, kiegészítve mindezt a bíróság jogalkalmazói tevékenysége körében felmerülő nehézségek bemutatásával, amihez a szerző közvetlen, 2019. január és február hónapjaiban szerzett jogalkalmazói tapasztalata szolgál alapul.

\section{A TÉMA AKTUALITÁSA A JOGTÖRTÉNET TÜKRÉBEN}

A szabálysértés jogintézményét a magyar jogrendszerben az 1953. évi 16. törvényerejű rendelet intézményesítette, ami azonban nem volt előzmény nélküli. Jogrendszerünk a kihágási büntető törvénykönyv, a Kbtk. megalkotása óta ismerte a kihágások jogintézményét, amit Király Tibor a büncselekmények olyan önálló csoportjaként írt le, amelyek kisebb jelentőségüknél fogva enyhébb vagy másfajta büntetéssel járnak, mint a többi büncselekmény, és amelyek más bíróság vagy hatóság elbírálása alá tartoznak, mint az egyéb bűncselekmények. ${ }^{2}$ Annak ellenére, hogy a kihágásokat Király Tibor definíciója a büntetöjog terrénumába vonta, a kihágásokat majd szabálysértéseket már a kezdetektől fogva jóval csekélyebb érdeklődés övezte a jogalkotó, illetve a jogtudomány részéről, mint a büntető anyagi vagy eljárásjogi kérdéseket. Ennek oka részint a kihágások, illetve szabálysértések jogági besorolása vonatkozásában, a jogtudományban mind a mai napig jelen lévő, eltérő álláspontokban rejlik, amit a következőképp fogalmazott meg Finkey Ferenc 1909. március 8. napján a Magyar Tudományos Akadémián felolvasott székfoglalójában: a kihágás „a büntetőjog és a közigazgatási jog határvillongása közben két szék közt a pad alá került. A büntetőjogász nem tartja magához méltónak azokkal foglalkozni, a közigazgatásjog művelői pedig óriási tárgyhalmazuk miatt azzal rázzák le magukról, hogy azok tárgyalása a büntetőjogba tartozik."3 A kihágások a szabálysértések 1953-as megjelenését követően még két évig voltak részei a magyar jogrendszernek, majd az 1955. évi 17. törvényerejü rendelet a kihágások nagyobb részét szabálysértéssé, kisebb részét pedig büncselekménnyé minősítette, ezzel megszüntetve a kihágások jogintézményét.

Király Tibor: Kihágások a magyar jogban. In Móra Mihály (szerk.): Tanulmányok az állam és a jog kérdései köréböl. Budapest, Jogi és Közgazdasági Könyvkiadó, 1953. 87.

Finkey Ferencz: A jogtalanság mint a büntetendő cselekmény ismérve. Székfoglaló értekezés. Budapest, 1909. 35. 
Finkey Ferenc székfoglalójának felolvasása óta már több mint egy évszázad telt el, és ez idő alatt több jogtudós foglalkozott mind a büntetőjog, ${ }^{4}$ mind pedig a közigazgatási jog ${ }^{5}$ neves művelői közül a szabálysértések mibenlétével, jogági besorolásával. A dogmatikai kérdések tisztázásán túl a szabálysértések vizsgálatát a jogalkalmazói gyakorlatban betöltött szerepük is messzemenőkig megalapozza. Az Országos Bírósági Hivatal (OBH) 2019. I. félévi ügyforgalmi adatai alapján a vizsgált félévben országos szinten 17922 peres szabálysértési ügy érkezett a járásbíróságokra (értve járásbíróságok alatt a fóvárosi kerületi bíróságokat is), ami 1936-tal meghaladja az ugyanezen időszakban a járásbíróságra érkező 15986 büntetőügy számát. A járásbíróságra érkező peres ügyek megoszlásában a szabálysértési ügyek ezzel 18,3\%-ot, míg a büntetöügyek 16,3\%-ot tettek ki. ${ }^{6}$ Ennél még erősebb eltérés mutatkozott a szabálysértési ügyek javára a nemperes ügyérkezés terén 2019. I. félévében, ugyanis, míg nemperes büntetőügyből 36757 érkezett a járásbíróságokra, addig szabálysértési nemperes ügyből $93074 .^{7}$ Mindezek alapján álláspontom szerint érdemes a szabálysértéseket gyakorlati oldalról megközelítve is vizsgálat tárgyává tenni.

\section{A JÁRÁSBÍRÓSÁGOK SZEREPE A SZABÁLYSÉRTÉSI ELJÁRÁSBAN}

Ezek után, ha megvizsgáljuk a járásbíróságok szerepét a szabálysértési jogalkalmazásban, akkor azt találjuk, hogy egyrészt e fórumra tartozik a hatósági szinten meghozott döntésekkel szemben előterjesztett kifogások elbírálása, másrészt pedig elsőfokon eljárva dönt a járásbíróság a szabálysértési elzárással is büntethető szabálysértések miatt indult eljárásokban. E - büntetőügyektől eltérő - kettős szerepet ${ }^{8}$ a szabálysértés jogintézményének Janus-arcú mivolta indukálja, amit Magyarország Alkotmánybírósága (AB) a 63/1997. (XII. 12.) számú határozatában a következőképp fogalmazott meg: „[A] szabálysértés kétarcú jogintézmény: a szabálysértések egy része úgynevezett közigazgatás-ellenes cselekmény (például engedélyköteles tevékenység engedély nélküli végzése), másik része pedig az emberi együttélés szabályait sértő magatartás, úgynevezett kriminális cselekmény (például a tulajdon elleni büncselekmények értékhatárral elválasztott alakzatai).” Eme kétarcúság pedig a következőket eredményezi a jogi szabályozásban az AB fenti határozata szerint: „a szabálysértési eljárás rendje inkább közelít az államigazgatási eljárás általános

4 Legfrissebb szakirodalom vonatkozásában lásd: Gellér Balázs - Ambrus István: A magyar büntetőjog általános tanai I. Budapest, ELTE Eötvös Kiadó, 2017. 35-40.

5 Az utóbbi időből lásd többek között: Fazekas Marianna - Ficzere Lajos: Magyar közigazgatási jog. Általános rész. Budapest, Osiris Könyvkiadó, 2006. 550.; Nagy Marianna: Quo vadis Domine? Elmélkedések a szabálysértések helyéről a 2012. évi szabálysértési törvény kapcsán. Jogtudományi Közlöny, (2012), 5. 217-226.

6 A polgári ügyek 61,7\%-ot, míg a gazdasági ügyek 3,7\%-ot képviselnek az összes járásbíróságra érkezett ügyből 2019. I. félévében.

Ügyforgalmi elemzés 2019. I. félév 36-37.

8 Kettős szerep alatt azt értem, hogy a járásbíróság bírája vagy bírósági titkára kifogások elbírálása során jogorvoslati fórumként, míg szabálysértési elzárással is büntethető szabálysértések vonatkozásában elsőfokú fórumként jár el. 
szabályaihoz, de a büntetőeljárás egyes elemeiből is építkezik”; míg „a szabálysértési felelösség - legyenek bár az elkövetett jogsértések igazgatásellenesek vagy kriminális jellegűek - alapvetően bűnfelelősség, azaz természetes személy múltban elkövetett jogsértésére válaszol, s a felróhatóság alapján meghatározott - represszív jellegü - joghátrányt helyez kilátásba”. Az idézett AB határozat szövegéből is jól kirajzolódnak a közigazgatási büntetőjog vegyesjogi jellemzői. Egyrészt, hogy a felelősségre vonás és a szankcionálás normái a büntető anyagi jog elveinek figyelembevételével születtek meg, másrészt, hogy a terület a fórumrendszer és az eljárás oldaláról markánsan kötődik a közigazgatási joghoz. ${ }^{9}$

A fent leírt kettős szerep megértése után még egy dimenziót szükséges vizsgálni, hogy teljes egészében rálátást nyerjünk a járásbíróság eljárására a szabálysértések terén, ugyanis akár jogorvoslati fórumként, akár elsőfokú szervként jár el a járásbíróság, a 2012. évi II. törvény a szabálysértésekről, a szabálysértési eljárásról és a szabálysértési nyilvántartási rendszerről (Szabs. tv.) meghatározott feltételek teljesülése esetén lehetőséget teremt arra, hogy a járásbíróság tárgyalás tartásával vagy tárgyaláson kívül bírálja el az adott ügyet.

Mindezeken túlmenően a végrehajtási szakban is megjelenhet a járásbíróság, amenynyiben a jogerős ügydöntő határozatban kiszabott szabálysértési pénzbírságot, helyszíni bírságot, illetve szabálysértési közérdekü munkát az eljárás alá vont személy önként nem, vagy csak részben teljesíti, akkor - ha azt a végrehajtásért felelős szerv indítványozza - a járásbíróság dönt a meg nem fizetett pénzbírság, helyszíni bírság, illetve le nem dolgozott közérdekű munka szabálysértési elzárásra történő átváltoztatásáról, főszabály szerint tárgyalás tartása nélkül, de az eljárás alá vont személy kérheti tárgyalás tartását.

A járásbíróság szabálysértési ügyek vonatkozásában betöltött szerepét az alábbi táblázat szemlélteti:

1. táblázat • Szabálysértési ügytípusok a járásbíróság előtt (Forrás: a szerző szerkesztése)

\begin{tabular}{|c|c|c|}
\hline $\begin{array}{c}\text { Szabálysértési hatóság } \\
\text { határozatával szemben } \\
\text { elöterjesztett kifogás elbírálása } \\
\text { jogorvoslati fórumként tárgyalás } \\
\text { tartása nélkül }\end{array}$ & $\begin{array}{c}\text { Szabálysértési elzárással is } \\
\text { büntethető szabálysértések } \\
\text { elsőfokú elbírálása tárgyalás } \\
\text { tartása nélkül }\end{array}$ & $\begin{array}{c}\text { Szabálysértési pénzbírság, } \\
\text { helyszíni bírság, illetve } \\
\text { szabálysértési közérdekü munka } \\
\text { átváltoztatása szabálysértési } \\
\text { elzárásra tárgyalás tartása nélkül }\end{array}$ \\
\hline $\begin{array}{c}\text { Szabálysértési hatóság } \\
\text { határozatával szemben } \\
\text { előterjesztett kifogás elbírálása } \\
\text { jogorvoslati fórumként } \\
\text { tárgyaláson }\end{array}$ & $\begin{array}{c}\text { Szabálysértési elzárással is } \\
\text { büntethető szabálysértések } \\
\text { elsőfokú elbírálása tárgyaláson }\end{array}$ & $\begin{array}{c}\text { Szabálysértési pénzbírság, } \\
\text { helyszíni bírság, illetve } \\
\text { szabálysértési közérdekủ munka } \\
\text { átváltoztatása szabálysértési } \\
\text { elzárásra tárgyaláson }\end{array}$ \\
\hline
\end{tabular}

Gellér-Ambrus (2017) i. m. 37. 


\section{ELJÁRÁSI REZSIM A SZABÁLYSÉRTÉSI ELZÁRÁSSAL IS BÜNTETHETŐ SZABÁLYSÉRTÉSEK ESETÉN}

Amint az a fenti táblázatból is kiolvasható, a szabálysértési elzárással is büntethető szabálysértések vonatkozásában a járásbíróság első fokon jár el. Az eljáró bíró, illetőleg bírósági titkár az elökészítő eljárásról készült jelentés bíróságra érkezését követően megvizsgálja az iratanyagot, hogy a tényállás tisztázott-e, szükséges-e álláspontja szerint az eljárás alá vont személy, tanú(k) vagy szakértő meghallgatása, illetőleg adottak-e az ügy vonatkozásában a közvetítői eljárás feltételei. Amennyiben az eljáró bíró, illetőleg bírósági titkár úgy ítéli meg, hogy a tényállás kellőképpen tisztázott, és az eljárásbeli személyek egyikének meghallgatása sem szükséges, továbbá a közvetítői eljárás feltételei sem állnak fenn, úgy az előkészítő eljárásról készült jelentés bíróságra érkezését követő 15 napon belül ügydöntő végzést hoz, amelyben az iratok és az előkészítő eljárásról szóló jelentés alapján büntetést szab ki, illetőleg intézkedést alkalmaz, valamint rendelkezik az eljárás költségeinek viseléséröl, illetőleg a szabálysértéssel okozott kár megtérítéséről. ${ }^{10}$ Ilyen esetben a bíróság végzésével szemben nincs helye fellebbezésnek, de az eljárás alá vont személy vagy képviselője a végzés kézhezvételétől számított nyolc napon belül tárgyalás tartását kérheti. ${ }^{11}$ Amenynyiben az iratok alapján meghozott végzés közlését követően az eljárás alá vont személy vagy képviselője kérésére tűz ki tárgyalást a járásbíróság, akkor relatív súlyosítási tilalom érvényesül, ugyanis határozatát az eljárás alá vont személy hátrányára csak akkor változtathatja meg, ha a tárgyaláson új bizonyíték merül fel. ${ }^{12}$

Egyébiránt a járásbíróság szabálysértési elzárással is büntethető szabálysértések elbírálása során akkor tart tárgyalást, ha az iratok alapján történő döntéshozatal feltételei nem állnak fenn, illetőleg, ha azok fennállnak, de valamely körülménynél fogva hivatalból szükségesnek tartja az ügy tárgyalás tartásával való elbírálását. ${ }^{13}$ Utóbbi esetkörre lehet példa, ha az iratok alapján úgy ítéli meg az eljáró bíró, illetve bírósági titkár, hogy szabálysértési elzárás kiszabása szükséges az eljárás alá vont személlyel szemben. Szabálysértési elzárás kiszabására ugyanis tárgyalás tartása nélkül - a 3/2007 (II. 13.) AB határozat következő megállapításával összhangban „a szabálysértési eljárás kriminális jellegéből következik, hogy a büntető eljárással szemben támasztott, Alkotmányban megfogalmazott követelményeknek ennek az eljárásnak is meg kell felelnie" - nem ad lehetőséget a Szabs. tv. ${ }^{14}$

Amennyiben a járásbíróság tárgyalás tartásával bírálja el az ügyet, úgy az iratok bíróságra érkezését követő 30 napon belül hozza meg ügydöntő végzését, ${ }^{15} \mathrm{ami}$ ellen a végzés közlésétől számított nyolc napon belül halasztó hatályú fellebbezést nyújthat be az eljárás alá vont személy, illetőleg képviselője, a bírósági tárgyaláson jelen lévő előkészítő eljárást

\footnotetext{
Szabs. tv. 118. \$(1)-(2) bek.

Szabs. tv. 119. $\$(1)$ bek.

Szabs. tv. 120. $\$(7)$ bek. 2. mondat.

Szabs. tv. 120. $\$(1)$ bek. 1. mondat.

Szabs. tv. 118. $\$(4)$ bek.

Szabs. tv. 107. $\$(2)$ bek.
} 
lefolytató szerv, továbbá a szabálysértéssel okozott kár megtérítésére kötelezés esetén - kizárólag ezen rendelkezés vonatkozásában - a sértett is. ${ }^{16} \mathrm{~A}$ fellebbezésre jogosultak vonatkozásában a Szabs. tv. a fent írtak szerint fogalmaz, azonban ez álláspontom szerint annyiban korrigálásra szorul, hogy a tárgyaláson nyilván nem az előkészítő eljárást lefolytató szerv mint jogi személy, hanem annak képviselője az, aki fellebbezést jelenthet be a bíróság ügydöntő végzésével szemben.

Amennyiben az eljárás valamely résztvevője fellebbezést jelent be a járásbíróság végzésével szemben, azt a törvényszék másodfokú tanácsa bírálja el az ügy iratainak törvényszékre érkezésétől számított 30 napon belül tanácsülésen. A törvényszék az elsőfokú határozatot az eljárás alá vont személy hátrányára csak az előkészítő eljárást lefolytató szerv képviselőjének, az eljárás alá vont személy terhére bejelentett fellebbezése esetén változtathatja meg. ${ }^{17}$

Tovább cizellálja az eljárásrendet, ha az eljárás alá vont személynek a szabálysértési elzárással is büntethető szabálysértés elkövetése miatti őrizetbe vételére kerül sor, és a rendőrség a gyorsított bírósági eljárás lefolytatása céljából az eljárás alá vont személyt bíróság elé állítja. Ilyen esetben, ha a fogva lévő eljárás alá vont személynek meghatalmazott képviselője nincs, a rendőrség intézkedik részére ügyvéd kirendelése iránt. ${ }^{18}$ Ezt követően a rendőrség biztosítja, hogy az eljárás alá vont személy képviselője az ügyet megismerhesse és az eljárás alá vont személlyel a tárgyalás időpontja előtt érintkezhessen. ${ }^{19}$ A rendőrség az iratokat és tárgyi bizonyítási eszközöket a tárgyaláson adja át a bíróság részére, majd szóban terjeszti elő a feljelentést, valamint javaslatot tesz a büntetés mértékére. ${ }^{20} \mathrm{~A}$ bíróság, amennyiben a tárgyalás megtartásának nincs akadálya - azaz az eljárás alá vont személyt képviselő ügyvéd vagy ügyvédjelölt jelen van, illetve az őrizetbe vétel kezdő időpontjától eltelt idő a 72 órát nem haladta meg -, meghallgatja az eljárás alá vont személyt, valamint szükség esetén a sértettet, illetve tanúkat, ${ }^{21}$ majd ezt követően - ha a közvetítői eljárásra utalás feltételei nem állnak fenn - meghozza az ügydöntő végzést, amit a jogorvoslati nyilatkozatok jegyzőkönyvbe vételét követően nyomban írásba is foglal, és kézbesít az eljárás alá vont személynek, képviselőjének, valamint a rendőrség képviselőjének. ${ }^{22}$

Fentiek alapján megállapítható, hogy a szabálysértési eljárások, még a büntetőeljárásról szóló 2017. évi XC. törvény innovatív, büntetőeljárásokat gyorsító és egyszerüsítő rendelkezéseivel összevetve is rendkívüli gyorsasággal zajlanak, kiváltképp gyorsított bíróság elé állítás esetén, amely nem kis kihívást jelent a bíróság számára, figyelemmel arra, hogy gyorsított bíróság elé állítás esetén a rendőrség a tárgyaláson adja át az eljáró bíró, illetve bírósági titkár részére az ügy iratait és a tárgyi bizonyítási eszközöket, így a rendelkezésre

\footnotetext{
Szabs. tv. 121. $\$(1)$ bek.

Szabs. tv. 122. $\$(1)$ bek.

Szabs. tv. 124. $\$$ (1) és (3) bek.

Szabs. tv. 124. $\$(4)$ bek.

Szabs. tv. 125. $\$(1)$ bek.

Szabs. tv. 125. $\$(3)$ bek.

Szabs. tv. 125. $₫(6)$ bek.
} 
álló felkészülési idő nagyon minimális, aminek következtében a tárgyalásvezetés különösen magas koncentrációt követel meg az eljáró bírótól, illetve bírósági titkártól. További nyomásként jelentkezik az időszerűség tartása, kiváltképp a fővárosban, ahol a rendőrség gyakran folyamatosan hozza bíróság elé állítás céljából az eljárás alá vont személyeket, így egy elhúzódó kihallgatás sorozatos megcsúszást jelenthet az adott napi tárgyalási rendben. Minderre jön még rá, hogy - a büntetőeljárásokkal ellentétben - a gyorsított bíróság elé állítások végén meghozott ügydöntő határozatoknak nemcsak a rendelkező részét, hanem az indokolását is nyomban írásba kell foglalnia az eljáró bírónak, illetve bírósági titkárnak. Arra, hogy mindezen nehézségekkel és nyomással mennyire eredményesen tudnak megbirkózni a fövárosban szabálysértési ügyeket tárgyaló bírák, illetve bírósági titkárok, álláspontom szerint az első fokon jogerőre emelkedő határozatok, valamint a másodfokon helybenhagyással záruló határozatok számarányából lehet következtetést levonni, amely adatokat a föváros vonatkozásában a későbbiekben ismertetni fogok.

\section{ELJÁRÁSREND A SZABÁLYSÉRTÉSI HATÓSÁG HATÁROZATÁVAL SZEMBEN ELÖTERJESZTETT KIFOGÁS ELBÍRÁLÁSA ESETÉN}

A járásbíróságnak lehetősége van a kifogás elbírálása során is tárgyalás tartása nélkül eljárni. Amennyiben az iratok alapján az eljárás lefolytatható és a kifogásban sem kérték tárgyalás tartását, úgy a járásbíróság ügydöntő végzését az iratoknak a bíróságra érkezésétől számított 15 napon belül meghozza. Ezt meghaladóan a járásbíróság akkor is mellőzheti tárgyalás tartását, ha azt ugyan a kifogásban kérték, de az iratok alapján azt állapítja meg, hogy a kifogás alapos és döntése a kifogásban foglaltakkal megegyezik, vagy azt az eljárás alá vont személy javára meghaladja. A bíróság akkor tart tárgyalást, ha ezt a kifogásban kérték és a fent kifejtettek szerint nem lát lehetőséget tárgyalás tartásának mellőzésére, valamint ha azt hivatalból szükségesnek tartja. ${ }^{23}$

Fontos kiemelni, hogy kifogás előterjesztése esetén relatív súlyosítási tilalom érvényesül, ugyanis a bíróság a határozatot az eljárás alá vont személy hátrányára csak jogszabály helytelen alkalmazása esetén változtathatja meg, feltéve ha a tárgyaláson új bizonyíték merül fel, aminek alapján a bíróság olyan új tényt állapít meg, amelynek folytán súlyosabb minősítést kell megállapítani vagy jelentős mértékben súlyosabb büntetést kell kiszabni. ${ }^{24}$

A bíróság végzése meghozatalakor jogerős, még akkor is, ha az az eljárás alá vont személyre nézve hátrányosabb rendelkezést tartalmaz, mint a szabálysértési hatóság határozatában foglaltak. A járásbíróság végzésével szembeni jogorvoslat hiánya ilyen esetekben alapjogi szempontból abból kifolyólag nem aggályos, hogy a járásbíróság második vagy - amennyiben a szabálysértési hatóság határozata ellen fellebbezésnek volt helye - harmadik fórumként vizsgálta meg az ügyet.

Szabs. tv. 109. \$, 110. $₫(1)$ bek.

Szabs. tv. 116. $\$(1)$ bek. c) pont, 116. $\$(1 a)$ bek. 


\section{A JÁRÁSBÍRÓSÁGOK SZEREPE A SZABÁLYSÉRTÉSI ELJÁRÁS VÉGREHAJTÁSI SZAKÁBAN}

Amennyiben az eljárás alá vont személy a jogerős ügydöntő határozatban kiszabott pénzbírságot, illetve helyszíni bírságot nem, vagy csak részben fizeti meg, illetőleg a szabálysértési közérdekủ munkát nem, vagy csak részben teljesíti, úgy a végrehajtásért felelös szerv a járásbíróságon indítványozhatja a meg nem fizetett pénzbírság vagy helyszíni bírság, illetve le nem dolgozott közérdekủ munka szabálysértési elzárásra történő átváltoztatását. Ilyen esetekben a bíróság az iratok megvizsgálását követően, ha az átváltoztatás törvényi feltételeinek hiányát állapítja meg, úgy melloozi az átváltoztatást, míg ha a végrehajtási eljárásban felmerült törvénysértést észlel, akkor a végrehajtásért felelős szervet a végrehajtási eljárás folytatására utasítja, vagy ha az alapeljárás vonatkozásában észlel törvénysértést, úgy az alapügyben hozott határozatot hatályon kívül helyezi és az alapeljárás lefolytatására jogosult szabálysértési hatóságot új eljárásra és új határozat meghozatalára kötelezi. ${ }^{25}$

Amennyiben a fentiek szerinti kizáró ok nem merül fel, úgy a bíróság az iratok érkezésétől számított öt napon belül végzést hoz, amelyben tájékoztatja az eljárás alá vont személyt az átváltoztatási indítvány tényéről, továbbá az önkéntes teljesítés előmozdítása érdekében tájékoztathatja az eljárás alá vont személyt az átváltoztatásra vonatkozó szabályokról, az átváltoztatást kizáró okokról, és felhívhatja az esetlegesen fennálló átváltoztatást kizáró oknak a végzés kézbesítésétől számított nyolc napon belül történő bejelentésére, valamint annak bejelentésére, hogy tárgyalás tartását kéri-e, egyben figyelmezteti, hogy amennyiben nem kéri tárgyalás tartását, úgy a bíróság anélkül határoz az átváltoztatás kérdésében. ${ }^{26}$

A bíróság a meg nem fizetett pénzbírság, illetve helyszíni bírság szabálysértési elzárásra való átváltoztatásáról rendelkező végzését az iratok bíróságra érkezésétől számított 45 napon belül hozza meg, amely ellen nincs helye jogorvoslatnak. ${ }^{27}$

Amellett, hogy jogi szempontból az egyik legkönnyebb megítélésü ügytípushoz sorolható véleményem szerint a szabálysértési pénzbírság, helyszíni bírság, illetve szabálysértési közérdekű munka szabálysértési elzárásra történő átváltoztatására irányuló nemperes eljárás, mégis nagyfokú együttműködést kíván a végrehajtásért felelős szerv és a járásbíróság között. A fővárosban a Pesti Központi Kerületi Bíróság Szabálysértési Csoportjában külön munkafolyamatot képez az átváltoztatási indítvánnyal beérkező iratanyagnak az úgynevezett előszürése. Számos esetben elöfordul ugyanis, hogy az elektronikus úton megküldött iratanyag hiányos, ami érdemi elbírálásra alkalmatlanná teszi az ügyet. Gyakran fordul elő az is, hogy a beszkennelt helyszínibírság-nyomtatvány fele lemarad, vagy a megküldött fájl tartalma homályos, olvashatatlan, így kellö bizonyossággal nem tud meggyőződni az eljáró bírósági titkár a helyszínibírság-nyomtatvány adattartalmáról. Szintén típushibaként említhető a közérdekű munka átváltoztatása körében, hogy az átváltoztatási

\footnotetext{
Szabs. tv. 141. $\$(7)$ bek., (13) bek. d), e) pontok.

Szabs. tv. 141. \$ (9) bek.

Szabs. tv. 141. $\$(8)$ bek.
} 
indítvány megtétele előtt a végrehajtásért felelős szerv nem keresi meg az eljárás alá vont személy tartózkodási helye szerint illetékes foglalkoztatási szervet a közérdekű munka teljesítése kapcsán, holott az eljárás alá vont személynek lehetősége van nemcsak az állandó lakóhelye, hanem a tartózkodási helye szerint illetékes foglalkoztatási szervvel is felvenni a kapcsolatot és teljesíteni a jogerős végzésben kiszabott közérdekű munkát. Ebből adódóan az eljárás alá vont személy tartózkodási helye szerint illetékes foglalkoztatási szerv nyilatkozata hiányában a járásbíróság nem tud érdemben állást foglalni az átváltoztatás feltételeinek fennállása körében.

\section{A PESTI KÖZPONTI KERÜLETI BÍRÓSÁG SZABÁLYSÉRTÉSI ÜGYEKBEN VALÓ JOGALKALMAZÓI GYAKORLATA A SZÁMOK TÜKRÉBEN ${ }^{28}$}

A jogi háttér és az egyes jogalkalmazói nehézségek után jelen fejezetben kitérek azon adatok bemutatására, amelyek birtokában az olvasó a címben feltett kérdést megválaszolhatja a maga számára.

A szabálysértési ítélkezési gyakorlat volumenének megismerése érdekében az újonnan érkező, a befejezett és a folyamatban maradt ügyek számát mutatom be először az elmúlt évek vonatkozásában, a következő diagram segítségével.

Az érkezett, befejezett és folyamatban maradt ügyek terén jelentkező tendenciózus változást még jobban szemlélteti, ha az egyes évek érkezett, befejezett és folyamatban maradt ügyeinek számát közvetlenül egymás mellé helyezzük, ahogy az a 2. diagramon látható.

Az 1-2. ábrák adattartalma alapján kiszámítható, hogy a Pesti Központi Kerületi Bíróság Szabálysértési Csoportja egész számra kerekítve 2015-ben havonta átlagosan 3496, 2016-ban 2692, 2017-ben pedig 2342 ügyet fejezett be. Látható az is, hogy 2015 óta az ügyérkezés jelentős mértékben töretlenül csökkent, ezzel párhuzamosan pedig 2016-tól a folyamatban maradt ügyek száma is folyamatosan csökkent. 2017-től kezdve a befejezett ügyek száma meghaladta az érkezett ügyek számát.

Ha külön megvizsgáljuk a táblázatban szereplö legfrissebb, 2018-as év számadatait, akkor azt találjuk, hogy egész számra kerekítve 2018-ban havonta átlagosan 1787 ügy érkezett, míg a befejezett ügyek száma havonta átlagosan 1802 volt. Ezáltal havonta átlagosan 15 üggyel többet fejeztek be, mint amennyi érkezett, így 2018-ban év végére 180-nal kevesebb ügy maradt folyamatban, mint az azt megelőző évben.

A 3. diagram a Pesti Központi Kerületi Bíróság Szabálysértési Csoportja egy tanácsra vetített havi átlag befejezésszámait szemlélteti 2017 és 2018 évek vonatkozásában.

Az e fejezetben szereplő statisztikai adatok megismerése és az előadás elkészítése körében nyújtott támogatásukért e helyen szeretnék köszönetet mondani dr. Bódisné dr. Besenyei Kingának, a Pesti Központi Kerületi Bíróság általános elnökhelyettesének és dr. Fekecs Beátának, a Pesti Központi Kerületi Bíróság Szabálysértési Csoport csoportvezető bírájának. 


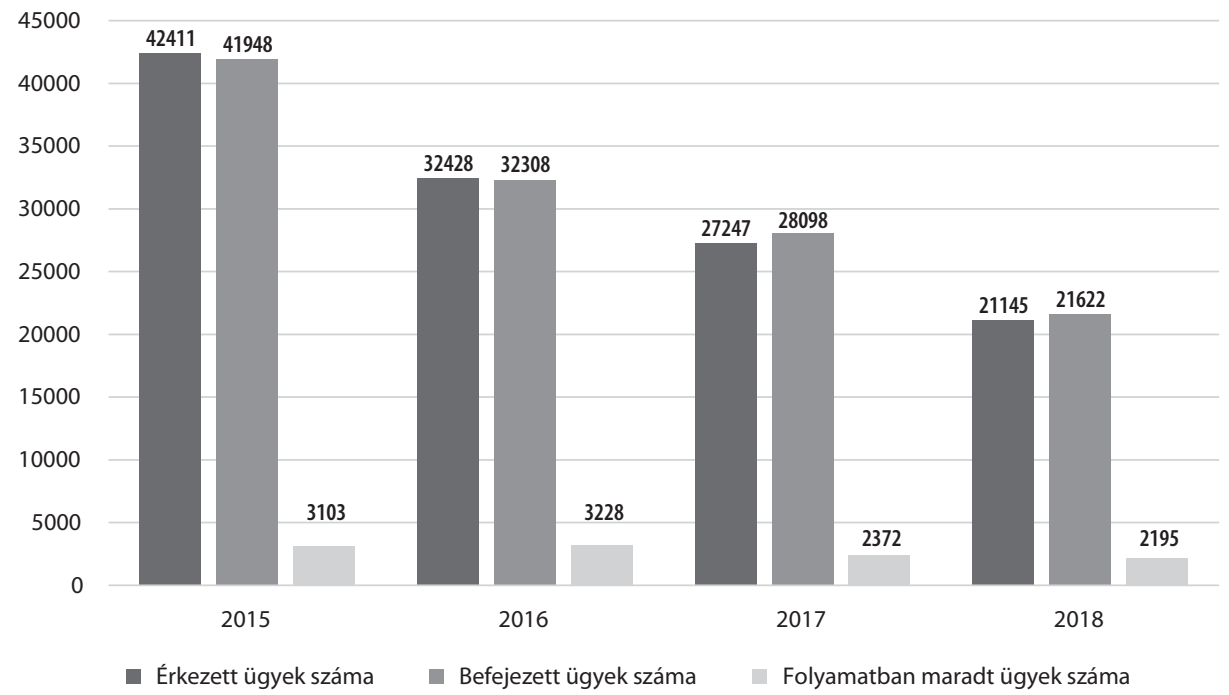

1. ábra • A PKKB által intézett szabálysértési ügyek száma 2015 és 2018 között (Forrás: a Pesti Központi Kerületi Bíróság Szabálysértési Csoportja részéről szolgáltatott adatok alapján a szerző szerkesztése)

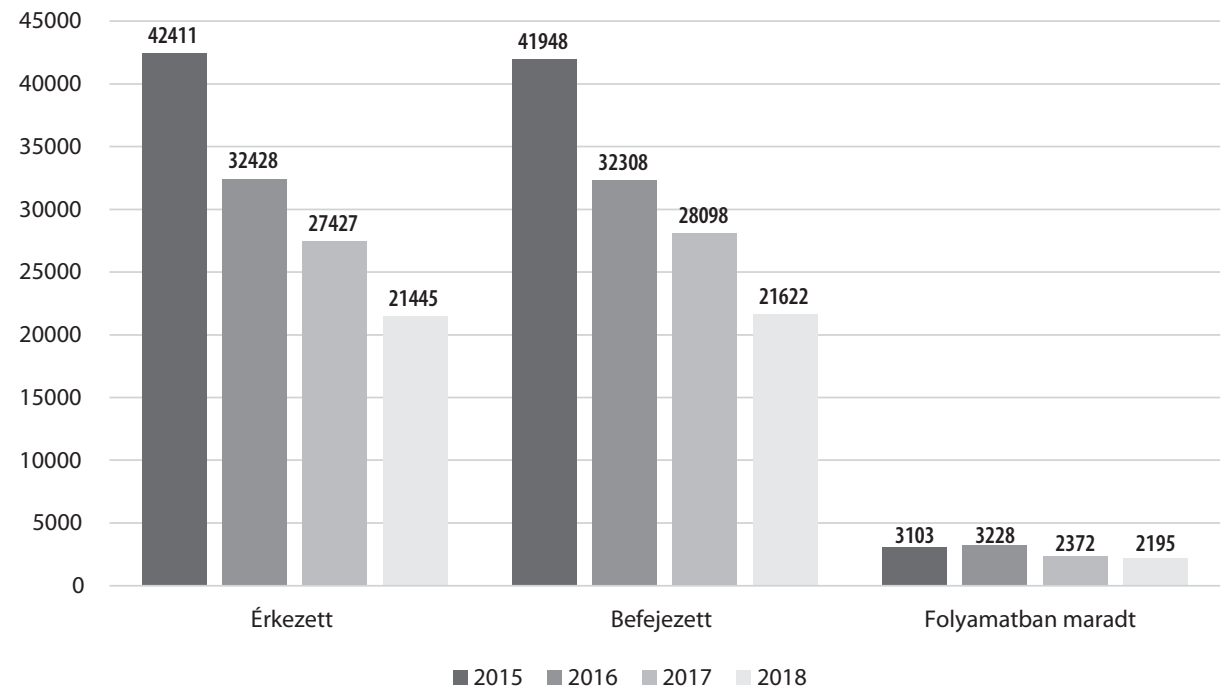

2. ábra • Érkezett, befejezett és folyamatban maradt ügyek száma 2015 és 2018 között (Forrás: a Pesti Központi Kerületi Bíróság Szabálysértési Csoportja részéről szolgáltatott adatok alapján a szerző szerkesztése) 


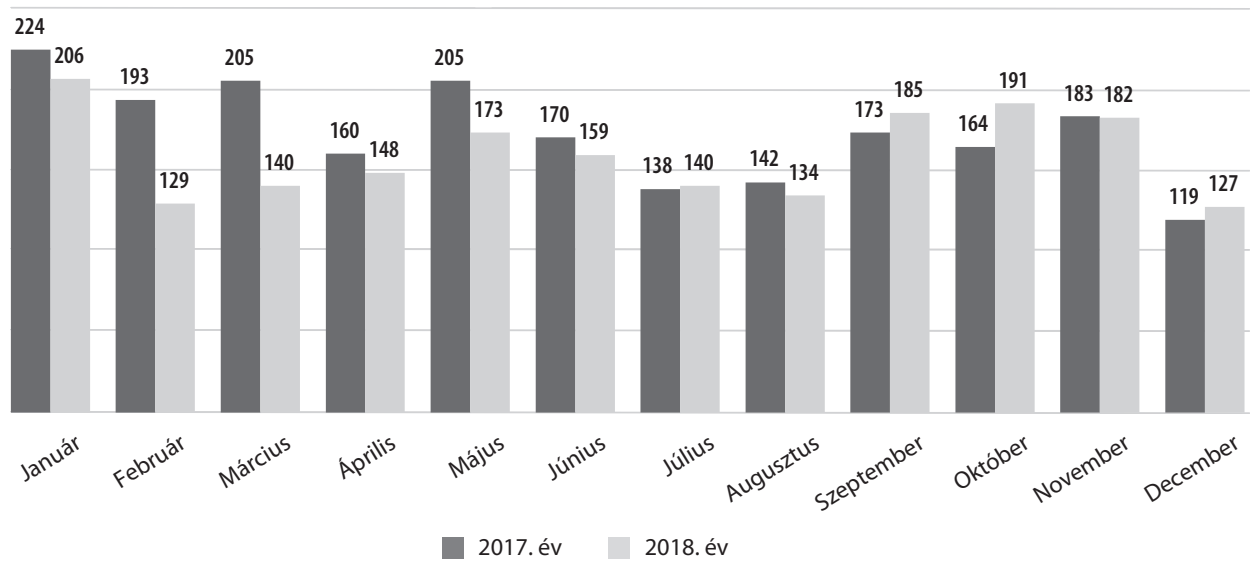

3. ábra • Egy tanács által befejezett ügyek száma

(Forrás: a Pesti Központi Kerületi Bíróság Szabálysértési Csoportja részéről szolgáltatott adatok alapján a szerző szerkesztése)

Ahhoz, hogy pontos képet kapjunk, miszerint egy adott tanácsra mekkora munkateher hárul a Pesti Központi Kerületi Bíróság Szabálysértési Csoportjában, további számításokat végeztem 2018. január hónap vonatkozásában, amikor a legmagasabb volt az egy tanácsra vetített befejezett ügyek száma. A naptárban való visszakeresés útján megállapítható, hogy 2018 januárjában összesen 22 munkanap volt, így egy további osztás segítségével kiszámítható, hogy egy tanács naponta átlagosan 9,36 ügyet fejezett be, amely meglátásom szerint egy nagyon magas szám.

A 3. diagram alapján további kiemelést érdemel, hogy a befejezések száma a nyári ítélkezési szünet idején ${ }^{29}$ sem esett vissza, olyannyira, hogy 2018 júliusában és augusztusában az egy tanácsra vetített átlagban befejezett ügyek száma külön-külön meghaladta az ugyanezen év februári, illetve decemberi befejezések átlagának számát.

A 4. kördiagram azt mutatja be, hogy az egyes szabálysértési ügytípusok aránya miként oszlott meg a Pesti Központi Kerületi Bíróságra érkezett valamennyi szabálysértési ügy vonatkozásában. A kördiagramon SZE-vel jelölöm a szabálysértési elzárással is büntethető ügyek miatt indult eljárásokat, SZK-val a szabálysértési kifogásokat, SZPÁ-SZKÁ-val a szabálysértési pénzbírság, helyszíni bírság, illetve közérdekű munka szabálysértési elzárásra történő átváltoztatása iránt indított eljárásokat, továbbá egy egyéb ügyek kategória jelöli a szabálysértési perújítás, valamint egyéb kategorizálatlan ügyek halmazát.

29 A nyári ítélkezési szünet ideje minden naptári évben július 15. és augusztus 20. napja közé esik. 


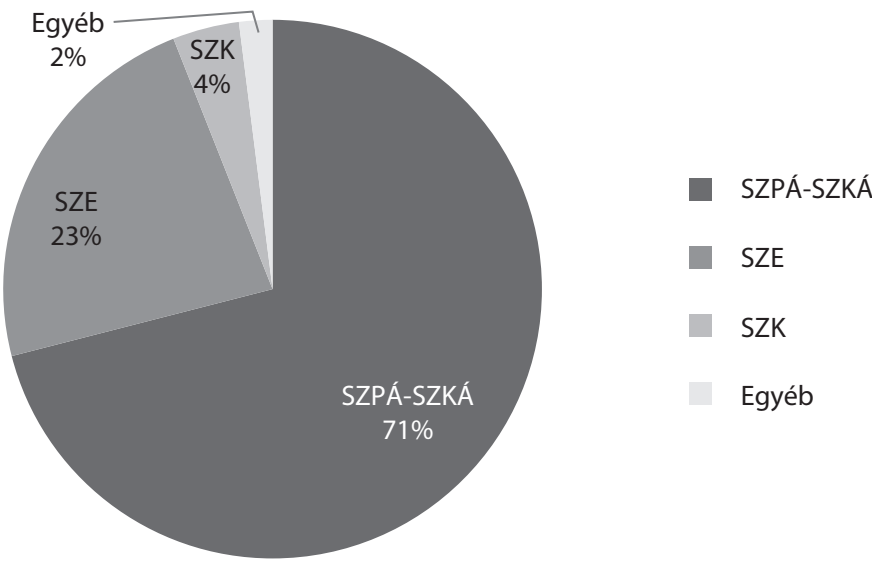

4. ábra • A PKKB-ra érkezett szabálysértési ügyek arány a különbözö ügycsoportok szerint (Forrás: a Pesti Központi Kerületi Bíróság Szabálysértési Csoportja részéröl szolgáltatott adatok alapján a szerzö szerkesztése)

A fenti számok, bár sok mindent elárulnak a Pesti Központi Kerületi Bíróság Szabálysértési Csoportjának munkájáról, azonban az ítélkezés „minőségébe” nem nyújtanak teljes körü betekintést. Ahhoz, hogy tovább árnyalhassam a képet, a következőkben a másodfokú bíróság - konkrétan a Fővárosi Törvényszék - felülbírálati tevékenységén keresztül vizsgálom a Pesti Központi Kerületi Bíróság Szabálysértési Csoportjának statisztikai mutatóit.

A korábbi fejezetek tartalmára visszautalva szabálysértési ügyekben ügydöntő határozatok vonatkozásában a szabálysértési elzárással is büntethető eljárásokban meghozott ügydöntő végzésekkel szemben van helye fellebbezésnek. Azonban, még e szükítés mellett is, ${ }^{30}$ már önmagában beszédes, hogy 2015-ben 61, 2016-ban 72, majd 2017-ben 63 esetben jelentettek be fellebbezést. Látható - kiváltképp a befejezések volumenének ismerete tükrében -, hogy igen csekély számban támadja fellebbezés az elsőfokú ügydöntő végzést. A fellebbezések száma vonatkozásában a vizsgált három évben nagyobb kilengés nem történt.

Az alábbi kördiagramok a Fővárosi Törvényszék másodfokú, felülbírálati tevékenységének tükrében mutatja be a Pesti Központi Kerületi Bíróság Szabálysértési Csoportjának munkáját a vizsgált évek vonatkozásában:

30 A fent bemutatott befejezésszámok valamennyi szabálysértési ügytípust magukban foglalják. 
2015: amikor összesen 61 ügyben jelentettek be fellebbezést

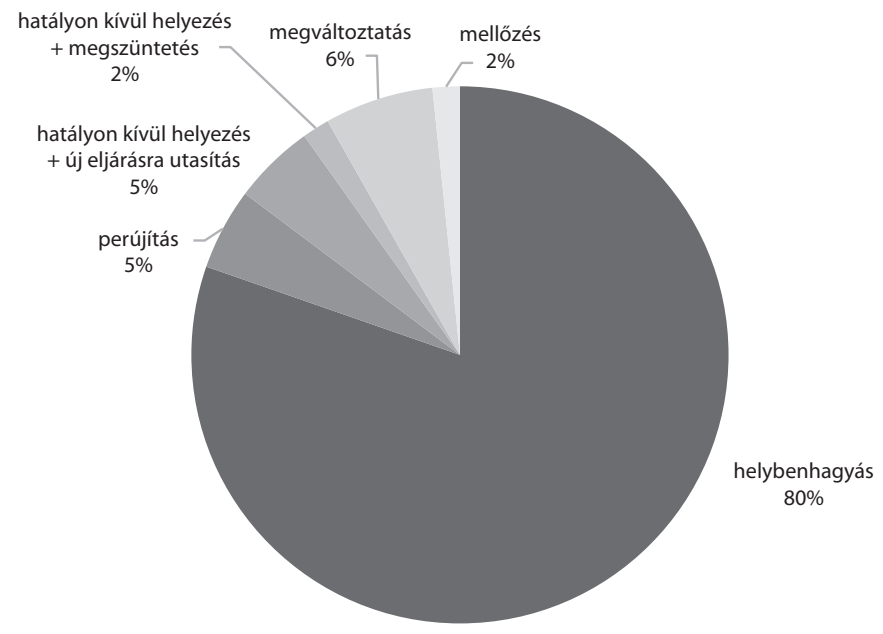

5. ábra • Másodfokú döntéstípusok aránya 2015-ben

(Forrás: a Pesti Központi Kerületi Bíróság Szabálysértési Csoportja részéről szolgáltatott adatok alapján a szerző szerkesztése)

2016: amikor összesen 78 ügyben jelentettek be fellebbezést

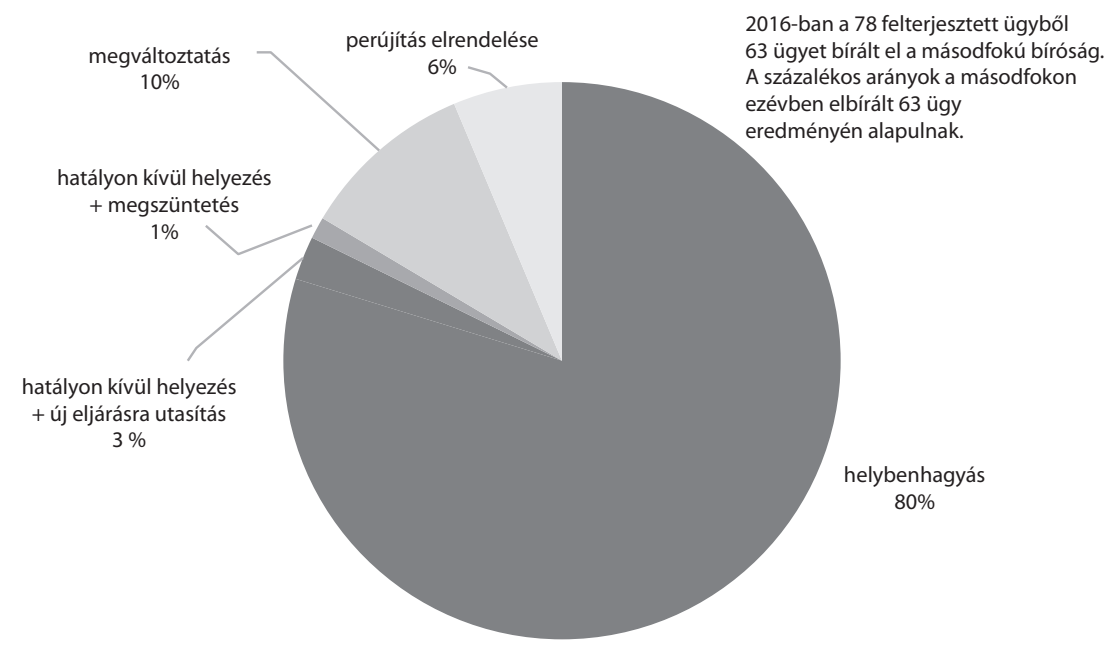

6. ábra • Másodfokú döntéstípusok aránya 2016-ban

(Forrás: a Pesti Központi Kerületi Bíróság Szabálysértési Csoportja részéröl szolgáltatott adatok alapján a szerző szerkesztése) 


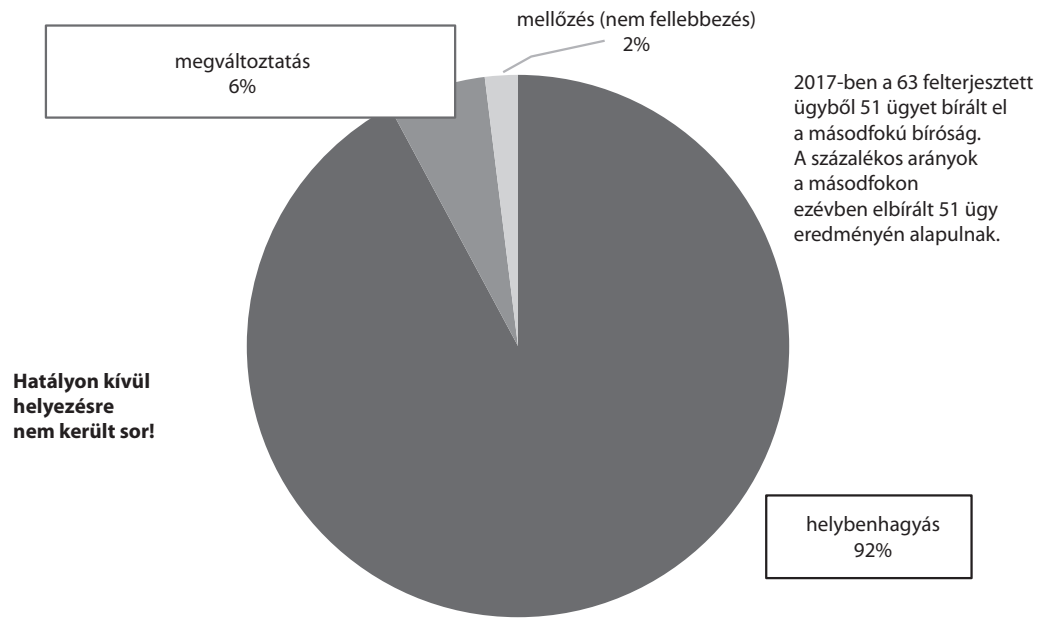

7. ábra • Másodfokú döntéstípusok aránya 2017-ben

(Forrás: a Pesti Központi Kerületi Bíróság Szabálysértési Csoportja részéről szolgáltatott adatok alapján a szerző szerkesztése)

\section{8. ÖSSZEGZÉS}

A Pesti Központi Kerületi Bíróság Szabálysértési Csoportjának ügyérkezése folyamatosan csökken, de az egy före jutó ügyteher magas. A vizsgált csoportban, ahol döntően bírósági titkárok látnak el ítélkezési tevékenységet ${ }^{31}$ többrétü kihívások jelentkeznek. Ahogy korábban bemutattam, az eljárási határidők valamennyi szabálysértési ügytípus vonatkozásában rövidek, amit tovább nehezít, miszerint - annak ellenére, hogy a szabálysértési elzárással is büntethető szabálysértések az állampolgárok alapvető életviszonyait érintik - a rendőrség által szabálysértési ügyek miatt folytatott előkészítő eljárások alapossága gyakran elmarad a büntetöügyek vonatkozásában végzett előkészítő eljárásokétól. A nehézségek ellenére a statisztikai adatok tükrében megalapozottan kijelenthető, hogy a Pesti Központi Kerületi Bíróság Szabálysértési Csoportjában magas színvonalú munkavégzés folyik, ezt támasztja alá különösen, hogy az elmúlt években a folyamatban maradt ügyek száma évről évre csökkent, a szabálysértési elzárással is büntethető ügyekben meghozott ügydöntő végzéseknek csak csekély számát támadta fellebbezés, és a fellebbezett ügyek tekintetében is kimagasló arányban születik az elsőfokú végzést helybenhagyó másodfokú döntés.

31 A fent részletesen elemzett 2018. januári hónapban például 1 bíró és 15 bírósági titkár, akikből két titkár 4 órában, egyikőjük pedig 6 órában dolgozott a Pesti Központi Kerületi Bíróság Szabálysértési Csoportjában. Ezen adatok a Pesti Központi Kerületi Bíróság intranet oldalán található információkon alapulnak. 


\section{FELHASZNÁLT IRODALOM}

1. Fazekas Marianna - Ficzere Lajos: Magyar közigazgatási jog. Általános rész. Budapest, Osiris, 2006.

2. Finkey Ferencz: A jogtalanság mint a büntetendö cselekmény ismérve. Székfoglaló értekezés. Budapest, 1909.

3. Gellér Balázs - Ambrus István: A magyar büntetőjog általános tanai I. Budapest, ELTE Eötvös Kiadó, 2017.

4. Király Tibor: Kihágások a magyar jogban. In Móra Mihály (szerk.): Tanulmányok az állam és a jog kérdései köréből. Budapest, Jogi és Közgazdasági Könyvkiadó, 1953.

5. Nagy Marianna: Quo vadis Domine? Elmélkedések a szabálysértések helyéröl a 2012. évi szabálysértési törvény kapcsán. Jogtudományi Közlöny, (2012), 5. 217-226.

Jogi források

1. 2012. évi II. törvény a szabálysértésekről, a szabálysértési eljárásról és a szabálysértési nyilvántartási rendszerről

2. 1955. évi 17. törvényerejű rendelet a kihágás intézményének és a kihágási bíráskodásnak megszüntetéséről

3. 1953. évi 16. törvényerejű rendelet a rendőrségi kihágási bíráskodás megszüntetése és a kihágási eljárásra vonatkozó egyes rendelkezések módosítása

4. 3/2007. (II. 13.) AB határozat

5. 63/1997. (XII. 12.) AB határozat

6. OBH Ügyforgalmi elemzése 2019. I. félév Elérhető: kpintra.justice.hu/sites/default/ files/ugyforgalom_2019.felev_.pdf [bírósági intraneten elérhető forrás] (A letöltés dátuma: 2020. 07.22.)

Dr. Illés Kristóf jelen tanulmányt a Fővárosi Törvényszék bírósági fogalmazójaként készítette el, aki a széles értelemben vett büntetőjog területén dolgozik a gyakorlatban. Érdeklődése fókuszában a nemzetközi elemet hordozó büntetőügyek állnak, kiváltképp a bírósági jogalkalmazás tükrében, azonban egyéb büntetőjogi vonatkozású témákban is előszeretettel végez kutatómunkát. 